\title{
Good Behavior Farmers Nilam Di Kabupaten Merangin Provinsi Jambi
}

\author{
Evo Afrianto dan M. Eka Wijaya \\ Program Studi Agribisnis Fakultas Pertanian Universitas Muara Bungo \\ email: evo_juventini@yahoo.com
}

\section{RINGKASAN}

Penelitian ini dilakukan untuk mengetahui Good behavior farmers, budidaya usahatani nilam dan hubungan Good behavior farmers dengan budidaya usahatani nilam di Kabupaten Merangin. Metode pengambilan sampel yang digunakan dalam penelitian ini adalah metode simple random sampling dan pemilihan daerah penelitian secara purposive dengan melihat tiga komponen perilaku yakni pengetahuan, sikap dan keterampilan dalam budidaya usahatani nilam. Analisis data perilaku petani dan budidaya usahatani nilam dilakukan secara deskriptif sedangkan analisis hubungan Good behavior farmers dengan budidaya usahatani nilam menggunakan uji Chi Square dengan kontingensi $2 \times 2$.

Hasil penelitian menunjukkan bahwa tingkat Good behavior farmers nilam di Kabupaten Merangin Provinsi Jambi dikategori rendah, baik pengetahuan, sikap maupun keterampilan petani. Untuk tingkat budidaya usahatani nilam di Kabupaten Merangin Provinsi Jambi tergolong rendah, baik penyiapan bahan tanam (bibit), penyiapan lahan, penanaman dan pemeliharaan tanaman, hanya panen yang tergolong rendah, sedangan untuk secara keseluruhan budidaya usahatani nilam di Kabupaten Merangin Provinsi Jambi tergolong rendah. Sedangkan Hubungan Good behavior farmers dengan budidaya usahatani nilam di Kabupaten Merangin Provinsi Jambi terdapat hubungan yang nyata.

Keyword : behavior farmers, Usahatani Nilam

\section{PENDAHULUAN}

\section{I.I Latar Belakang}

Pembangunan disektor pertanian merupakan bagian integral dari pembangunan nasional terus diupayakan, mengingat bahwa negara Indonesia adalah negara agraris yang mana sebagian besar penduduknya masih bertumpu hidup pada sektor pertanian. Salah satu penyumbang devisa Negara adalah minyak nilam dimana Indonesia merupakan pemasok terbesar kebutuhan minyak nilam dunia, yakni sekitar 90\% dari seluruh kebutuhan dunia. Minyak nilam menyumbang lebih dari $50 \%$ total ekspor minyak atsiri Indonesia sehingga diharapkan dapat menjadi komoditas minyak atsiri unggulan di pasar ekspor. Negara yang bersaing dipasar dunia adalah RRC, Brazil, India, dan Malaysia. Sedangkan Negara sasaran ekspor minyak nilam Indonesia antara lain : Jepang, Belanda, Singapura, Argentina, Malaysia, Amerika Serikat, Inggris Prancis, Jerman, Brazil, Italia, Spanyol, Swedia, India, Pakistan, Hongkong, Saudi Arabia, Uni Emirat Arab, Fillipina, Australia, Belgia, Luxemburg, Polandia, Korea, dan Swiss (Rukmana, 2004)

Menurut Mangun (2005), wilayah yang telah mengembangkan nilam di Indonesia adalah Aceh, Sumatera Utara, Bengkulu, 
Sumatera Barat, Lampung, Jawa Barat, Jawa Tengah, Jawa Timur, dan Kalimantan Tengah (Daerah Transmigrasi) sedangkan Provinsi Jambi belum terdata (tidak diperhitungkan yang disebabkan luas dan produksinya masih terbatas). Tetapi Provinsi Jambi adalah salah satu provinsi yang mengusahai usahatani nilam yang diusahakan di Kabupaten Merangin, dimana tahun 2014 luas lahan nilam sampai sebesar $1.385 \mathrm{Ha}$, tetapi produksi usahatani nilam di Kabupaten Merangin masih rendah, rendahnya produksi di duga adanya kesalahan perilaku petani dalam budidaya usahatani nilam yang tidak sesuai dengan anjuran. Perilaku petani disini adalah segala penghayatan, kegiatan atau aktivitas petani dalam berusahatani. Menurut Notoadmodjo (2003), perilaku merupakan totalitas penghayatan dan aktivitas seseorang yang merupakan hasil bersama atau resultan antara berbagai faktor baik faktor internal maupun faktor eksternal. Berdasarkan permasalahan diatas maka penulis tertarik menulis dengan judul "Good Behavior Farmers Nilam di Kabupaten Merangin Provinsi Jambi”.

\subsection{Rumusan Masalah}

1. Good behavior farmers nilam di Kabupaten Merangin Provinsi Jambi?

2. Budidaya usahatani nilam di Kabupaten Merangin Provinsi Jambi?

3. Hubungan Good behavior farmers dengan budidaya usahatani nilam di Kabupaten Merangin Provinsi Jambi?

\subsection{Hipotesis}

1. Mengetahui Tingkat Good behavior farmers nilam di Kabupaten Merangin Provinsi Jambi?

2. Mengetahui Tingkat Budidaya usahatani nilam di Kabupaten Merangin Provinsi Jambi?

3. Menganalisis Hubungan Good behavior farmers dengan budidaya usahatani nilam di Kabupaten Merangin Provinsi Jambi?

\section{METODE PENELITIAN}

Metode penelitian yang digunakan dalam penelitian ini adalah metode deskriptif analisis, yaitu suatu metode untuk meneliti status kelompok manusia, suatu objek, suatu kondisi, suatu sistem pemikiran ataupun suatu peristiwa pada saat sekarang. Selanjutnya teknik penelitian dilksanakan dengan menggunakan teknik survey yang memiliki ciri khas bahwa data dikumpulkan dari responden dengan menggunakan kuesioner (Singarimbun dan Effendi, 1995)

Data yang diperoleh dari responden terlebih dahulu di sederhanakan secara tabulasi. Untuk mempelajari perilaku petani dan budidaya usahatani nilam dianalisis secara deskriptif. Untuk mengetahui hubungan antara perilaku petani dengan budidaya usahatani nilam di lakukan analisis Chi Square dengan kontingen 2x2. Menurut Siegel (1997) dengan uji Chi square dengan kontingen $2 \times 2$ menggunakan rumus sebagai berikut :

$$
\chi^{2}=\frac{N[(A D-B C)]^{2}}{(A+B)(C+D)(A+C)(B+D)}
$$

Sedangkan bila terdapat sel yang berisi frekuensi kurang dari 5 digunakan rumus sebagai berikut :

$$
\chi^{2}=\frac{N\left[(A D-B C)-\frac{N}{2}\right]^{2}}{(A+B)(C+D)(A+C)(B+D)}
$$

Keterangan :

$\mathrm{N}=$ Jumlah sampel

\begin{tabular}{cccc}
\hline $\begin{array}{c}\text { Good } \\
\text { behavio } \\
\boldsymbol{r}\end{array}$ & \multicolumn{2}{c}{$\begin{array}{c}\text { Budidaya } \\
\text { usahatani nilam }\end{array}$} & Jumlah \\
\cline { 2 - 3 } fingg & Rendah & \\
\hline Positif & $\mathrm{A}$ & $\mathrm{B}$ & $\mathrm{A}+\mathrm{B}$ \\
Negatif & $\mathrm{C}$ & $\mathrm{D}$ & $\mathrm{C}+\mathrm{D}$ \\
\hline Jumlah & $\mathrm{A}+\mathrm{C}$ & $\mathrm{B}+\mathrm{D}$ & \\
\hline
\end{tabular}

Nilai $\left(\chi^{2}\right)$ pada tabel derajat bebas ( $\mathrm{Db})=1$ Pada tingkat kepercayaan $95 \%$ adalah 
3.84 dapat di bandingkan antara $\chi^{2}$ hitung dengan $\chi^{2}$ tabel dengan keputusan sebagai berikut :

1. Jika $\chi^{2}$ hitung [ $\left(\chi^{2} \leq \chi^{2} \alpha=5 \% \mathrm{db}=(\right.$ b-1) ( k-1) ] terima Ho

2. Jika $\chi^{2}$ hitung $\left[\left(\chi^{2} \geq \chi^{2} \alpha=5 \% \mathrm{db}=(\mathrm{b}-\right.\right.$ 1) ( k-1) ] tolak Ho

Dimana:

H0 = Tidak terdapat hubungan Good behavior farmers terhadap budidaya nilam di Kabupaten Merangin

H1 = Terdapat hubungan Good behavior farmers terhadap budidaya nilam di Kabupaten Merangin

Selanjutnya untuk mengukur derajat hubungan antara kedua variable di gunakan koefisien kontingensi dengan rumus sebagai berikut.

$$
C=\sqrt{\frac{\chi^{2}}{\chi^{2}+N}}
$$

Dimana :

$\chi^{2}=\chi^{2}$ hitung

$\mathrm{N}=$ Jumlah sampel

$\mathrm{C}=$ Koefisien Kontingensi, nilai ini teletak antara $0-0,707$

Selanjutnya Untuk Mengukur keeratan hubungan digunakan formulasi :

$$
\begin{aligned}
r & =\frac{\text { Chit }}{c M a x} \\
C \max & =\sqrt{\frac{m-1}{m}}=\sqrt{\frac{1}{2}}=0,707 \\
r & =\frac{\sqrt{\frac{\chi^{2}}{\chi^{2}+N}}}{\sqrt{\frac{m-1}{m}}}
\end{aligned}
$$

Keterangan :

$\mathrm{r} \quad=$ Koefisien keeratan hubungan

$\chi^{2}=$ Nilai uji Chi Square

$\mathrm{N}=$ Jumlah sampel

$\mathrm{m}=$ Jumlah kolom/baris pada tabulasi silang. dengan kategori :

a. Hubungan digolongkan lemah apabila nilai terletak antara $0-0,353$.

b. Hubungan digolongkan kuat apabila nilai terletak antara $0,353-0,707$.

Dimana artinya adalah berhasil atau tidaknya ditentukan oleh sebesar ... \% Selanjutnya untuk melihat adanya hubungan atau tidak maka di gunakan formulasi yakni :

$\mathrm{t}_{\text {hit }}=\sqrt{\frac{N-2}{1-(r)^{2}}}$

dimana

$\mathrm{H} 0 ; \mathrm{r}=0$

$\mathrm{H}_{1} ; \mathrm{r} \neq 0$

Jika t hitung $(\leq \mathrm{t}$ tabel $=(\alpha=5 \% \mathrm{db}=\mathrm{N}-2)\}$

Terima Ho

Jika t hitung $(\geq \mathrm{t}$ tabel $=(\alpha=5 \% \mathrm{db}=\mathrm{N}-2)\}$

Tolak Ho

Dimana :

$\mathrm{H} 0=$ Tidak terdapat hubungan yang signifikan antara Good behavior farmers terhadap budidaya usahatani nilam di Kabupaten Merangin

$\mathrm{H1}=$ Terdapat hubungan yang signifikan antara Good behavior farmers terhadap budidaya usahatani nilam di Kabupaten Merangin

\section{HASIL DAN PEMBAHASAN}

\subsection{Tingkat Good behavior farmers nilam}

Good behaviour farmers merupakan totalitas penghayatan dan aktivitas seseorang yang merupakan hasil bersama atau resultan antara berbagai faktor baik faktor internal maupun faktor eksternal. Perilaku dapat berbentuk reaksi sikap positif atau negatif terhadap objek yang ditunjukkan oleh manusia. perilaku terdiri dari tiga komponen yaitu pengetahuan, sikap, keterampilan.

\subsubsection{Pengetahuan}

Pengetahuan merupakan segala sesuatu yang diketahui oleh seseorang terhadap objek dari penggunaan panca indra karena adanya unsur 
yang mengisi akal secara nyata. Pengetahuan memberikan landasan bagi keinginan untuk melaksanakan sesuatu. Pengetahuan dalam penelitian ini adalah pengetahuan petani dalam membudidayakan usahatani nilam. diketahui bahwa $68 \%$ petani memiliki pengetahuan yang kurang menguasai, artinya mengindikasikan bahwa petani kurang menguasai budidaya usahatani nilam yang sesuai dengan anjuran

\subsubsection{Sikap}

Sikap merupakan kecenderungan yang bersifat negatif dan positif terhadap objek psikologis. Objek psikologi disini meliputi : simbol, kata-kata. slogan orang, lembaga, ide dan sebagainya. Orang dikatakan memiliki sikap positif terhadap objek psikologi apabila ia suka (like) atau memiliki sikap yang favorable, sebaliknya orang yang dikatakan memiliki sikap negatif terhadap objek psikologi bila la tidak suka (dislike) atau sikapnya unfavorable terhadap objek psikologi. Dalam penelitian ini diketahui bahwa $72 \%$ petani memiliki sikap yang kurang mendukung, artinya mengindikasikan bahwa petani yang kurang mendukung budidaya usahatani nilam yang sesuai dengan anjuran

\subsubsection{Keterampilan}

Keterampilan adalah kecekatan, kecakapan, atau kemampuan untuk melakukan sesuatu dengan baik dan cermat sesuai dengan keahlian. Keterampilan juga diartikan adalah kemahiran dalam pelaksanaan sesuatu yang dicapai dengan latihan. Dalam penelitian ini diketahui bahwa 64 $\%$ petani kurang terampil, artinya mengindikasikan bahwa petani kurang terampil melakukan budidaya usahatani nilam yang sesuai dengan anjuran.

\subsection{Budidaya Usahatani Nilam}

Budidaya usahatani nilam sangat menentukan dalam upaya meningkatkan produksi sehingga diperoleh hasil yang sesuai dengan yang diharapkan. Budidaya usahatani nilam ini terdiri dari lima komponen yaitu penyiapan bahan tanaman (bibit), penyiapan lahan, penanaman, pemeliharaan tanaman, dan panen.

\subsubsection{Penyiapan Bahan Tanaman (Bibit)}

Nilam diperbanyak dengan setek yang diambil dari batang atau cabang yang sudah mengayu dari bagian tanaman yang belum terlalu lama, tetapi tidak muda lagi, diambil dari pohon induk yang berumur lebih dari setahun. Setek yang dipilih untuk bibit harus sehat dan bebas dari penyakit. Setek yang diambil dapat ditanam secara langsung ataupun melalui persemaian terlebih dahulu. Diketahui dalam penelitian ini bahwa $62 \%$ petani melakukan penyiapan bahan tanaman (bibit) nilam tergolong rendah, artinya mengindikasikan bahwa petani kurang menguasai, kurang mendukung dan kurang terampil dalam penyiapan bahan tanaman (bibit) nilam yang sesuai dengan anjuran

\subsubsection{Penyiapan Lahan}

Penyiapan lahan atau pengolahan tanah dilakukan terlebih dahulu untuk mampu menciptakan lahan pakai menjadi lebih baik dan sesuai bagi tanaman yang akan ditanam. Tanah dicangkul $\pm 30 \mathrm{~cm}$, selanjutnya dibuat bedengan dengan lebar dan tinggi $3 \mathrm{~m} \mathrm{x} 40 \mathrm{~cm}$ diberi pupuk kandang 2 ton/ha kemudian kemudian diberi masa bera selama 13 - 14 hari. diketahui dalam penelitian ini bahwa $68 \%$ petani melakukan penyiapan lahan tergolong rendah, artinya mengindikasikan bahwa petani kurang menguasai, kurang mendukung dan kurang terampil dalam penyiapan lahan sebagai media tanaman nilam yang sesuai dengan anjuran.

\subsubsection{Penanaman}

Penanaman nilam sangat baik dilakukan pada musim hujan karena tanaman nilam membutuhkan tanah yang lembab pada masa pertumbuhannya. Penanaman dapat dilakukan secara langsung dan tidak langsung. Penanaman langsung yaitu bibit yang sudah diambil langsung ditanam pada lahan yang sudah 
dipersiapkan sedangkan penanaman secara tidak langsung yaitu penanaman yang dilakukan melaui penyemaian terlebih dahulu. Penanaman nilam oleh petani di daerah penelitian terdiri dari $56 \%$ tergolong rendah, artinya mengindikasikan bahwa petani kurang menguasai, kurang mendukung dan kurang terampil dalam penanaman nilam yang sesuai dengan anjuran.

\subsubsection{Pemeliharaan Tanaman}

Pemeliharaan tanaman dilakukan sejak tanaman sudah ditanam hingga tanaman siap dipanen atau berkisar antara $6-8$ bulan. Beberapa kegiatan yang dilakukan dalam pemeliharaan tanaman adalah penyulaman, pengairan, pemulsaan, pemupukan, penyiangan dan pembumbunan, penjarangan, pemangkasan dan pengaturan tanaman, serta pengendalian hama dan penyakit. Pemeliharaan tanaman nilam yang dilakukan petani didaerah penelitian tergolong rendah yaitu $62 \%$, artinya mengindikasikan bahwa petani kurang menguasai, kurang mendukung dan kurang terampil dalam pemeliharaan tanaman nilam yang sesuai dengan anjuran.

\subsubsection{Panen}

Panen dapat dilakukan setelah tanaman nilam pada umur 6 sampai 8 bulan. Pemanenan dilakukan dengan pemangkasan atau memotong cabang-cabang, ranting-ranting, dan. daun-daun tanaman dengan menggunakan gunting, atau parang yang tajam. Pemanenan tanaman nilam yang dilakukan di daerah penelitian sebagian besar tergolong tinggi yaitu 66\%, artinya mengidikasikan bahwa patani sangat menguasai, sangat mendukung dan sangat terampil dalam pemanenan nilam dari pengalaman-pengalaman memanen sebelumnya ataupun dari pengalaman pemanenan komoditi lainnya yang secara tidak langsung sesuai dengan anjuran budidaya usahatani nilam.

Berdasarkan kelima komponen diatas yang terdiri dari penyiapan bahan tanaman (bibit), penyiapan lahan, penanaman, pemeliharaan tanaman dan panen dapat diketahui bahwa $60 \%$ petani yang melakukan budidaya usahatani nilam tergolong rendah. artinya mengindikasikan bahwa petani kurang menguasai, kurang mendukung, dan kurang terampil dalam membudidayakan usahatani nilam yang sesuai dengan anjuran.

\subsection{Hubungan Good behavior farmers Petani dengan Budidaya Usahatani Nilam}

Good behavior farmers dalam budidaya usahatani nilam tidak terlepas dari ketiga komponen perilaku petani yang terdiri dari pengetahuan, sikap, dan keterampilan petani dalam mengelola usahatani nilam yang dimiliki. Analisis aspek perilaku petani dalam budidaya usahatani nilam.

Berdasarkan uji statistik (uji chi square) didapatkan nilai $\mathrm{x}^{2}$ hitung adalah 28,017 dan $\mathrm{x}^{2}$ tabel 3,84, $\mathrm{x}^{2}$ hitung [ $\left(\chi^{2} \geq \chi^{2} \alpha=5 \% \mathrm{db}=(\right.$ b-1) ( k-1) ] tolak $\mathrm{H}_{0}$, perbedaan perilaku petani menyebabkan perbedaan budidaya usahatani nilam.

Selanjutnya setelah didapatkan nilai $\mathrm{x}^{2}$ hitung didapatlah $\mathrm{C}_{\text {hit }}$ yakni $\quad 0,599$ dan $\mathrm{C}_{\text {maks }}$ 0,707, artinya hubungan Good behavior farmers nilam tergolong kuat. Keeratan hubungannya sebesar 0,847 , artinya $84,7 \%$ tinggi rendahnya budidaya usahatani nilam dipengaruhi oleh perilaku petani. Selanjutnya didapatkan nilai $t_{\text {hit }}$ 11,030 dan $t_{\text {tabel }} 1,686, t_{\text {hit }}\left(\geq t_{\text {tabel }}=(\alpha=5 \% \mathrm{db}\right.$ $=48)\}$ tolak $\mathrm{H}_{0}$, artinya Good behavior farmers nilam berhubungan nyata.

\section{KESIMPULAN DAN SARAN}

\subsection{Kesimpulan}

1. Tingkat Good behavior farmers nilam di Kabupaten Merangin Provinsi Jambi dikategori rendah, baik pengetahuan, sikap maupun keterampilan petani.

2. Budidaya usahatani nilam di Kabupaten Merangin Provinsi Jambi tergolong rendah, 
baik penyiapan bahan tanam (bibit), penyiapan lahan, penanaman dan pemeliharaan tanaman, hanya panen yang tergolong rendah, sedangan untuk secara keseluruhan budidaya usahatani nilam di Kabupaten Merangin Provinsi Jambi tergolong rendah.

3. Hubungan Good behavior farmers dengan budidaya usahatani nilam di Kabupaten Merangin Provinsi Jambi terdapat hubungan yang nyata.

\subsection{Saran}

1. Pemerintah diharapkan menyediakan faktor produksi seperti bibit, pupuk obat-obatan serta menyediakan alat produksi seperti mesin penyulingan dan mesin pemotongan tanaman nilam.

2. Sebaiknya petani didampingi oleh pihak penyuluh baik dari pemerintah maupun swasta tentang teknik budidaya usahatani nilam mulai dari penyediaan tanaman, penyiapan lahan, penanaman, pemeliharaan tanaman sampai pemanenan.

\section{DAFTAR PUSTAKA}

Ahmadi Ahmad.1988. Psikologi Sosial. Penebar Swadaya. Jakarta.

Dinas Kecamatan Sungai Tenang. 2009. Sungai Tenang dalam Angka di Kecamatan Sungai Tenang.

Dinas Kehutanan dan Perkebunan Kabupaten Merangin. 2008. Luas Areal dan Produksi Nilam di Provinsi Jambi tahun 2003-2007.

Dinas Kehutanan dan Perkebunan Kabupaten Merangin. 2009. Luas Areal, Produksi, dan Rata-rata Produksi Nilam di Kecamatan dalam Kabupaten Merangin tahun 2008.

Dinas Koperasi Perindustrian dan perdagangan Kabupaten Merangin 2009. Profit Unggulan Indag Kabupaten Merangin.
Dinas Pertanian RI. 2006. Undang-undang No. 16 Tahun 2006 Tentang Sistem Penyuluhan Pertanian, Perikanan dan Kehutanan. Jakarta.

Hernanto Fadholi. 1993. Ilmu Usahatani.

Penebar Swadaya. Jakarta

Jakarta.

Karninan dan mauludi. 2004. Nilam Tanaman Semak Beraroma Wangi untuk Industri Parfum dan Kosmetik. Agromedia Pustaka. Jakarta.

Koentjaraningrat. 1990. Pengantar Ilmu Antropologi. Rineka Cipta. Jakarta

Mangun. 2008. Nilam Seri Agribisnis. Penebar Swadaya. Surabaya.

Mardikanto Totok. 1993. Penyuluhan Pembangunan Pertanian. UNS Pres. Surakarta. 2009. Sistem Penyuluhan Pertanian.

UNS Pres. Surakarta.

Mosher. Artur . 1991. Menggerakkan dan Membangun Pertanian. Yasaguna. Jakarta.

Notoatmodjo Soekidjo. 2003. Pendidikan dan Perilaku Kesehatan. Rineka Cipta.

Jakarta.

Rukmana Rahmat 2004. Nilam : Prospek Agribisnis dan Teknik Budidaya. Kanisius. Yogyakarta

Siegel. 1990. statistik non parametrik untuk ilmu-ilmu sosial. Gramedia. Jakarta

Singarimbun. M dan Effendi. S. 1995. Metode Penelitian Survey. LP3ES. Jakarta

Soekanto. 1998. Sosiologi Suatu Pengantar. Raja Grapindo Persada. Jakarta

Soekartawi. 1984. Prinsip Dasar Komunikasi Pertanian. Universitas Indenesia.

Sudaryani dan Sugiharty. 1989. Budidaya dan Penyulingan Minyak Nilam. Penebar Swadaya. Jakarta. 